\title{
Investigation of the Cause of Precocious Puberty in an 8-Year-Old Girl Ended up in Juvenile Granulosa and Theca Cell Tumor of the Ovary
}

\author{
Mahtab Ordooei $^{1}$, Mojgan Karimi-Zarchi ${ }^{2 *}$, Golnaz Malekzadeh ${ }^{3}$, Mansour Moghimi ${ }^{4}$ \\ ${ }^{1}$ Department of Pediatrics, Pediatric Endocrinologist, Shahid Sadoughi University of Medical Sciences, Yazd, Iran; ${ }^{2}$ Gynecology \\ Oncology Department, Shahid Sadoughi Hospital, Yazd, Iran; ${ }^{3}$ Shahid Sadoughi University of Medical Sciences, Yazd, Iran; \\ ${ }^{4}$ Department of Pathology, Shahid Sadoughi University of Medical Sciences, Yazd, Iran. \\ Email: *drkarimi2001@yahoo.com
}

Received March $6^{\text {th }}, 2013$; revised April $5^{\text {th }}, 2013$; accepted April 14 ${ }^{\text {th }}, 2013$

Copyright (C) 2013 Mahtab Ordooei et al. This is an open access article distributed under the Creative Commons Attribution License, which permits unrestricted use, distribution, and reproduction in any medium, provided the original work is properly cited.

\begin{abstract}
Isosexual precocious puberty in girls has several etiologies. Juvenile granulose cell tumor is one of the rarest causes that only stands for $1.5 \%$ of ovarian cancers. This tumor mostly encounters in first 2 decades of life. This paper is a report of an 8-year-old girl with precocious puberty that within five months developed breast enlargement followed by menarche. Works which are done to find the underlying cause of precocious puberty revealed juvenile granulosa cell tumor in her left ovary. She then under went laparoscopic surgery and 3 courses of chemotherapy. She did not experience any vaginal bleeding after that and the serum level of estradiol lay among its normal ranges, but after that the tumor relapsed and presented as abdominal pain and a huge mass which under went resection of all afflicted tissues. After 2 courses of chemotherapy, her status deteriorated and unfortunately she died after 6 months from the time of diagnosis. Treatment for this disease is consists of resection surgery and chemotherapy. If this tumor is diagnosed in its early stages, it will be curable, but in its advanced stages, up to $80 \%$ of patients die from recurrent tumors. The reported patient was diagnosed at stage IIIC that had poor prognosis.
\end{abstract}

Keywords: Precocious Puberty; Juvenile Granulosa Cell Tumor; Ovary

\section{Introduction}

Juvenile granulosa cell tumor of the ovary (JGCT) is a subset of ovarian cancers and stands for almost $5 \%$ of all ovarian malignancies [1]. It can be distinct from its adult type that mostly occurs in post menopausal women due to different clinical and pathological features such as hirsutism, abdominal discomfort and abnormal vaginal bleeding. Juvenile type has higher mitotic activity and nuclear atypicality as well as the expression of PCNA and $\mathrm{p} 53$, but has poor prognosis in comparison to adult type [2]. This tumor has the potential to produce hormones that lead to early presentation and diagnosis [3]. The complaint that is common among these patients is a palpable mass in lower abdomen. Ascites in $10 \%$ of them is reported [4]. This tumor can present in divers ages from infancy to teenage but it mostly presents in the age of 8 or 9 years old [5].

This tumor is rarely reported before [6-15], this paper

"Corresponding author. is a report of an 8-year-old girl who presented iso sexual precocious puberty and works which are done to find the underlying cause ended up in Juvenile granulosa and theca cell tumor of the ovary.

\section{Case Presentation}

The patient was an 8 year old girl from Yazd in an only child family from high socioeconomic level with the height of $142 \mathrm{~cm}$ and weight of $34 \mathrm{~kg}$, who presented breast enlargement compatible with Tanner III. About five months from first bud of breasts, she started vaginal bleeding but no presentation of pubic or auxiliary hair. She was referred to pediatric endocrinologist to investigate the cause of precocious puberty. In physical exam the vital sign was stable everything was normal but a large mass in left side of abdomino pelvic cavity was palpated. No peripheral lymphadenopathy or organomegaly was detected. She had no complaint of pain or nausea, vomiting or other complaint of any kind. The lab 
results indicated normal thyroid function and Cell Blood Count $(\mathrm{CBC})$ but impaired serum level of gonadal hormones. Folicle stimulating hormone (FSH) was $0.2(0.1$ $4.3 \mathrm{IU} / \mathrm{lit})$, luteinizing hormone was 1.9 (0.1 - $5 \mathrm{IU} / \mathrm{lit})$, stradiol was $120.9(6-27 \mathrm{pg} / \mathrm{ml})$, serum cortisol of $8 \mathrm{AM}$ was $15 \mu \mathrm{g} / \mathrm{dl}(5-23 \mu \mathrm{g} / \mathrm{dl})$. Advanced bone age was also detected that was around 12 years old. Other lab tests consist of liver function test was normal but a high Lactate dehyrogenase was reported which was $1040 \mathrm{U} / 1$ (up to $580 \mathrm{U} / \mathrm{l})$. Alkaline phosphatase was $664 \mathrm{U} / 1$ (180 1200 ) and urine analysis showed moderate amorph urate crystal. Electrolytes consist of $\mathrm{Na}, \mathrm{K}, \mathrm{Ca}, \mathrm{P}$ were all in their normal ranges. In the sequence order abdominopelvic sonography was done. It showed a lobulated echogenic solid mass in left part of abdomen with the diameter of $4 \mathrm{~cm}$ and free fluid in abdomen especially in pelvis and under the liver. For further assessment CT scan with intravenous contrast was done. The result showed a large $20 * 11 \mathrm{~cm}$ multiloculated cystic mass with marked septation and loculation in left side of abdomino pelvic cavity that has the pressure effect on the pelvic and abdominal content. Ovarian cystadenoma, mucinous cystadenoma or other pelvic masses were suggested. Some of tumor markers also were elevated. Carbohydrate antigen $19-9$ was $6.2 \mathrm{U} / \mathrm{ml}$ (up to 39), carbohydrate antigen 125 was $469 \mathrm{U} / \mathrm{ml}$ (up to 35), carcinoembryonic antigen (CEA) was $0.44 \mathrm{ng} / \mathrm{ml}(0.0$ - 5), beta HCG (beta Human Chorionic Gonadotropin) was $0.1 \mathrm{mIU} / \mathrm{ml}$ (up to 5.3 ), alpha feoto protein was $1.2 \mathrm{IU} / \mathrm{ml}(0.0-5.8)$ and inhibin A was $320 \mathrm{pg} / \mathrm{ml}(<2.2 \mathrm{pg} / \mathrm{ml})$. Patient was referred to gynecologist and the tumor was resected by Laparoscopic surgery. Histopathology and ascites fluid cytology confirmed the rare ovarian tumor of Juvenile granulosa and theca cell. High mitotic activity with wide necrotic parts and calcified and bizarre nuclei was seen (Figures 1 and 2). In immunohisto chemistry CD99 (Cluster of Differentiation 99), BCL2 (B-cell lymphoma 2), PR (progesterone receptor), CKAE1/AE3 (Cytokeratin AE1/ AE3) was reported positive which is compatible with juvenile granulose cell tumor (Figures 3 and 4). Then

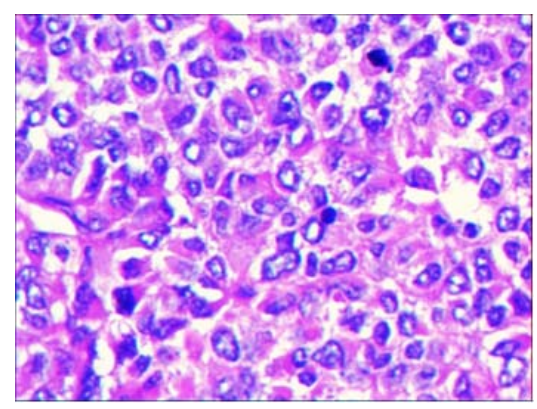

Figure 1. JGCT with high mitotic rate and moderate to abundant eosinophilic to vacuolated cytoplasm and round, hyperchromatic nuclei lacking grooves (H \& E 40X).

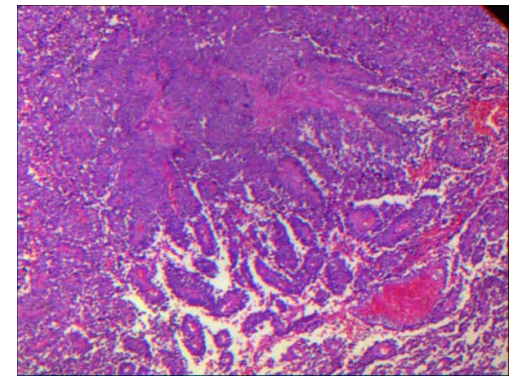

Figure 2. JGCT with pseudopapillary architecture (H \& E 4X).

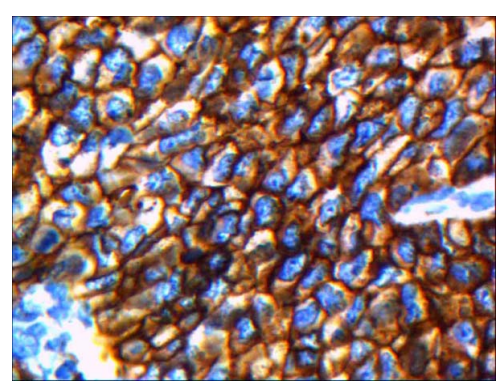

Figure 3. JGCT, Diffuse membranous CD99 positivity is characteristic (IHC 40X).

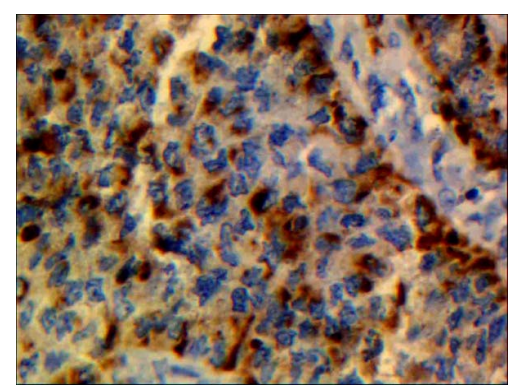

Figure 4. JGCT, patchy weak cytoplasmic staining for CKAE1/AE3 (IHC 40X).

chemotherapy of BEP consists of Bleomycin, Etoposide and Cisplatin started for her. After the third course of chemotherapy the tumor relapsed with the presentation of abdominal pain and huge mass. Because of the relapse of tumor patient went under complete resection of tumor, left oophorectomy, appendectomy and resection of intestine and peritonea which the tumor adhered to them. Only uterine, right ovary and fallopian tube were preserved. The stage of the tumor was equivalent to III C. Chemotherapy of BEP continued for her but after the second course, her status deteriorated. She had dyspnea which then hospitalized and metastasis to lungs was detected. Despite all procedures done on her unfortunately she died after 6 months passed from diagnosis.

\section{Discussion}

Ovarian juvenile granulosa cell tumors are rare malignant 
tumors afflict young girls. As this tumor mostly secreted hormones, the most common presentation is precocious puberty, premature thelarche and vaginal bleeding [16] that all goes along with this reported patient's presentation. Due to tumor derived estradiol, she had advanced bone age compatible with the age of 12 years old.

On CT scan and sonography, JGCT most typically appears as large, multilocular mass [17]. In this case, also a large multi loculated cystic mass with marked septation and loculation in left side of abdomino pelvic cavity was seen.

Diagnosis of JGCT in pathology may be confused with other ovarian tumors with pseudopapillary pattern; immunohistochemistry can be used in more problematic cases [18]. These tumors are characteristically positive for inhibin, calretinin, Vimentin and keratin [19]. In this patient, $\mathrm{CD}_{99}$ and Cytokeratin AE1/AE3 were reported positive. In 6 cases reviewed by Kavuri et al, diffuse positivity for vimentin in all of them was reported but the staining for cytokeratin (AE1/AE3) and calretinin was negative. Four cases expressed CD99 and 1 case was positive for inhibin [20].

The most important prognostic factor is tumor stage. The tumors with the size of more than $5 \mathrm{~cm}$, mitotic figures more than $10 \mathrm{in} \mathrm{hpf}$ and The more degree of nuclear atypia have poor prognosis [21,22]. The treatment is also related to the stage of the tumor, but selective treatment in early stages is unilateral salpingo oophorectomy and then starting the chemotherapy [23]. Cisplatin had shown good results in treatment of these patients [24]. BEP (Bleomycin, Etoposide and Cisplatin) is also recommended for chemotherapy [24] but if the tumor excised completely in early stages, adjuvant therapy may not be necessary [25].

Inhibin is dimeric glycoprotein secreted from ovarian granulose cells. It is a good marker to follow up patients and diagnose any recurrence [26-28]. In previous studies, Activin B was also reported as a good marker to monitor the patients [29].

As this tumor mostly presented in juveniles, preservation of fertility in patients is an important issue which can be reached by early diagnosis, tumor resection, chemotherapy and strict follow up. The patient's disease was diagnosed less than 5 months and went under surgery twice and 5 courses of BEP chemotherapy which lead to regression in breast size and decrease in the serum estradiol level but unfortunately the tumor outnumbered all treatments and she expired after 6 months.

\section{Conclusion}

According to the high prevalence of functional cysts in comparison to neoplastic masses in childhood, malignnancies may be underdiagnosed and mismanaged. So consideration of the clinical features along with preclinical investigations can result in earlier diagnosis and a better prognosis.

\section{REFERENCES}

[1] S. Jamieson and P. J. Fuller, "Molecular Pathogenesis of Granulosa Cell Tumors of the Ovary," Endocrine Reviews, Vol. 33, No. 1, 2012, pp. 109-144. http://dx.doi.org/10.1210/er.2011-0014

[2] J. N. Huang, Y. Z. Liu and X. M. Zhang, "Clinical Analysis of Juvenile Ovary Granulose Celltumor," Zhonghua Fu Chan Ke Za Zhi, Vol. 42, No. 8, 2007, pp. 533-536.

[3] G. V. Koukourakis, V. E. Kouloulias, M. J. Koukourakis, G. A. Zacharias, C. Papadimitriou, K. Mystakidou, K. Pistevou-Gompaki, J. Kouvaris and A. Gouliamos, "Granulosa Cell Tumor of the Ovary: Tumor Review," Integrative Cancer Therapies, Vol. 7, No. 3, 2008, pp. 204-215. http://dx.doi.org/10.1177/1534735408322845

[4] N. Kalfa, P. Philibert, C. Patte, E. Thibaud, C. Pienkowski, A Ecochard, B. Boizet-Bonhoure, M. Fellous and C. Sultan, "Juvenile Granulosa-Cell Tumor: Clinical and Molecular Expression," Gynecologie Obstetrique \& Fertilite, Vol. 37, No. 1, 2009, pp. 33-44.

http://dx.doi.org/10.1016/j.gyobfe.2008.06.026

[5] L. Merras-Salmio, K. Vettenranta, M. Mottonen and M. Heikinheimo, "Ovarian Granuolosa Cell Tumors in Childhood," Pediatric Hematology/Oncology, Vol. 19, No. 3, 2002, pp. 145-156.

http://dx.doi.org/10.1080/088800102753541297

[6] F. J. Cameron, I. Scheimberg and R. Stanhope, "Precocious Pseudopuberty Due to a Granulosa Cell Tumour in a Seven-Month-Old Female," Acta Paediatrica, Vol. 86, No. 9, 1997, pp. 1016-1018. http://dx.doi.org/10.1111/j.1651-2227.1997.tb15193.x

[7] F. Raafat, H. Klys and G. Rylance, "Juvenile Granulosa Cell Tumor,” Pediatric Pathology, Vol. 10, No. 4, 1990, pp. 617-623.

http://dx.doi.org/10.3109/15513819009067150

[8] N. A. Fleming, J. de Nanassy, S. Lawrence and A. Y. Black, "Juvenile Granulosa and Theca Cell Tumor of the Ovary as a Rare Cause of Precocious Puberty: Case Report and Review of Literature," Journal of Pediatric \& Adolescent Gynecology, Vol. 23, No. 4, 2010, pp. e127e131. http://dx.doi.org/10.1016/j.jpag.2010.01.003

[9] S. Ellouze, S. Krichen-Makni, K. Trabelsi, L. Ayadi, A. Sellami, A. Khabir, S. Hammami, H. Mnif and T. Sellami-Boudawara, "Granulosa-Cell Tumor of the Ovary: Report of 16 Cases," Journal de Gynecologie, Obstetrique et Biologie de la Reproduction (Paris), Vol. 35, No. 8, 2006, pp. 767-772. http://dx.doi.org/10.1016/S0368-2315(06)76477-8

[10] V. Bognoni, A. Quartuccio and P. Geraci, "Ovarian Granulosa Cell Tumor of Juvenile Type Associated with Pregnancy. Clinical Case and Review of the Literature," Minerva Ginecologica, Vol. 49, No. 6, 1997, pp. 283-287.

[11] M. Kdous, R. Hachicha and A. Gamoudi, "Early Isosex- 
ual Precocious Pseudopuberty Revealing a Juvenilegranulosa Cell Tumor in a Six-Year-Old Girl," Gynecologie Obstetrique \& Fertilite, Vol. 32, No. 4, 2004, pp. 311-314. http://dx.doi.org/10.1016/i.gyobfe.2004.02.009

[12] A. Mouko, D. Moukassa, X. Leroy, J. Ibara, E. Makosso, G. Bikandou, R. M. Kalengayi and P. Senga, "Early Isosexual Precocious Pseudopuberty Revealing a Juvenile Granulosa Cell Tumor in a 3-Year-Old Congolese Girl," Annales De Pathologie, Vol. 20, No. 3, 2000, pp. 245248.

[13] G. A. Saeed and N. Farooq, "Precocious Pseudopuberty Due to Juvenile Granulosa Cell Tumor," Journal of College of Physicians and Surgeons Pakistan, Vol. 13, No. 5, 2003, pp. 287-288.

[14] T. Adachi, H. Sato, S. Nakayama, S. Shimizu, H. Matsui and M. Nakabayashi, "Primary Amenorrhea Due to Juvenilegranulosa-Cell Tumor of the Ovary: A Case Report," Journal of Obstetrics and Gynaecology Research, Vol. 38, No. 3, 2012, pp. 597-600. http://dx.doi.org/10.1111/j.1447-0756.2011.01735.x

[15] D. Larizza, V. Calcaterra, P. Sampaolo, G. Lanati, P. Brambilla, T. Mondello and S. Cesari, "Unusual Presentation of Juvenile Granulosa Cell Tumor of the Ovary," Journal of Endocrinological Investigation, Vol. 29, No. 7, 2006, pp. 653-656.

[16] P. Geetha and M. K. Nair, "Granulosa Cell Tumours of the Ovary," Australian and New Zealand Journal of Obstetrics and Gynaecology, Vol. 50, No. 3, 2010, pp. 216220. http://dx.doi.org/10.1111/j.1479-828X.2010.01154.x

[17] H. K. Faber, "Meigs' Syndrome with Thecomas of Both Ovaries in a 4-Year-Old Girl," Journal of Pediatrics, Vol. 61, No. 5, 1962, pp. 769-773. http://dx.doi.org/10.1016/S0022-3476(62)80353-9

[18] J. A. Irving and R. H. Young, "Granulosa Cell Tumors of the Ovary with a Pseudopapillary Pattern: A Study of 14 Cases of an Unusual Morphologic Variant Emphasizing Their Distinction from Transitional Cell Neoplasms and Other Papillary Ovarian Tumors," The American Journal of Surgical Pathology, Vol. 32, No. 4, 2008, pp. 581-586. http://dx.doi.org/10.1097/PAS.0b013e31815c186f

[19] Y. N. Zhang and S. F. Huang, "Clinicopathologic Study of Juvenilegranulosa Cell Tumor of Ovary," Zhonghua Bing Li Xue Za Zhi, Vol. 39, No. 10, 2010, pp. 661-665.

[20] S. Kavuri, R. Kulkarni and M. Reid-Nicholson, "Granulosa Cell Tumor of the Ovary: Cytologic Findings," Acta Cytologica, Vol. 54, No. 4, 2010, pp. 551-559.

[21] D. Schmidt and F. Kommoss, "Diagnosis and Differential
Diagnosis of Granulosa Cell Tumor," Pathologe, Vol. 28 , No. 3, 2007, pp. 195-202. http://dx.doi.org/10.1007/s00292-007-0908-8

[22] A. Auranen, J. Sundström, J. Ijäs and S. Grénman, "Prognostic Factors of Ovarian Granulosa Cell Tumor: A Study of 35 Patients and Review of the Literature," International Journal of Gynecological Cancer, Vol. 17, No. 5, 2007, pp. 1011-1018.

http://dx.doi.org/10.1111/j.1525-1438.2007.00914.x

[23] E. Bouffet, T. Basset, N. Chetail, F. Dijoud, P. Mollard, M. Brunat-Mentigny and M. David, "Juvenile Granulosa Cell Tumor of the Ovary in Infants: A Clinicopathologic Study of Three Cases and Review of the Literature," Journal of Pediatric Surgery, Vol. 32, No. 5, 1997, pp. 762-765.

http://dx.doi.org/10.1016/S0022-3468(97)90029-4

[24] D. T. Schneider, G. Calaminus, R. Wessolowski, et al., "Therapy of Advanced Ovarian Juvenile Granulosa Cell Tumors," Klinische Pädiatrie, Vol. 214, No. 4, 2002, pp. 173-178. http://dx.doi.org/10.1055/s-2002-33183

[25] Y. Wang, W. Y. Wang, C. Xu, X. R. Huang, L. Zhong, X. L. Kang, Z. J. Yang and Y. H. Liu, "Childhood Ovarian Juvenile Granulosa Cell Tumor: A Retrospective Study With 3 Cases Including Clinical Features, Pathologic Results, and Therapies," Journal of Pediatric Hematology/ Oncology, Vol. 33, No. 3, 2011, pp. 241-245.

[26] P. Flemming, A. Wellmann, H. Mascheck, H. Lang and A. Georgii, "Monoclonal Antibodies against Inhibin Represent Key Markers of Adult Granulosa Tumors of the Ovary Even in Their Metastases," The American Journal of Surgical Pathology, Vol. 19, No. 8, 1995, pp. 927-933. http://dx.doi.org/10.1097/00000478-199508000-00008

[27] X. Matias-Guiu, C. Pons and J. Prat, "Mullerian Inhibiting Substance, Alphainhibin, and CD99 Expression in Sex Cord-Stromal Tumours and Endometrioid Ovarian Carcinomas Resembling Sex Cord-Stromal Tumours," $\mathrm{Hu}$ man Pathology, Vol. 29, No. 8, 1998, pp. 840-845. http://dx.doi.org/10.1016/S0046-8177(98)90454-3

[28] S. Jamieson and P. J. Fuller, "Management of Granulosa Cell Tumour of the Ovary," Current Opinion in Oncology, Vol. 20, No. 5, 2008, pp. 560-564. http://dx.doi.org/10.1097/CCO.0b013e328306316f

[29] K. K. Vihko, M. Blaur, U. Puistola and P. Tuohimaa, "Activin B in Patients with Granulosa Cell Tumors: Seruom Levels in Comparison to Inhibin," Acta Obstetricia et Gynecologica Scandinavica, Vol. 82, No. 6, 2003, pp. 570-574. http://dx.doi.org/10.1034/j.1600-0412.2003.00146.x 